\title{
Cobb-Douglas production function on FDI in Southeast Europe
}

\author{
Mico Apostolov
}

${ }^{*}$ Correspondence: mico.apostolov@ugd.edu.mk UGD, Krste Misirkov b.b., P.O. Box 201, 2000 Stip,

Macedonia

\begin{abstract}
In this research, we focus on effects of foreign direct investments in Southeast European economies. Using World Bank Microdata Library and specifically Enterprise Surveys, we take a sample of six countries. The model is based on firm-level data of a representative sample of economy's private sectors for Albania, Bosnia and Herzegovina, Croatia, Macedonia, Serbia and Slovenia. What we are closely examining are the effects of foreign direct investments on the development of domestic firms and the overall economy. Foreign direct investment is usually defined as dominant or controlling ownership of a company in one country, by an entity based in another country. Transition economies undergo a set of structural transformations intended to develop market-based institutions through economic liberalization, where prices are set by market forces. Hence, foreign direct investments remain main concern as major source of capital utilized toward enterprise restructuring. This research is built on Cobb-Douglas production function where data are analyzed with econometric models, which as employed in this study examines the interrelationships between output and set of variables that influence foreign direct investments arrangements. Additionally, according to the results, estimates are specified on the ways foreign direct investments mold the economy.
\end{abstract}

Keywords: FDI effects, Output, Southeast Europe

JEL Classification: D01, F21, G11, G31, L33, O11, P31

\section{Background}

The study is to be focused on probing effects of foreign direct investments in Southeast Europe economies. Hence, six countries have been taken as sample for this research: Albania, Bosnia and Herzegovina, Croatia, Macedonia, Serbia and Slovenia.

The World Bank has conducted Enterprise Surveys on many countries using firm-level data of a representative sample of economy's private sectors. What we are closely examining are the effects of foreign direct investments on the development of domestic firms and the overall economy. Indeed, foreign direct investments remain main concern as major source of capital directed toward enterprise restructuring. Using data of Southeast Europe will be scrutinized the interrelationships between output and set of variables that influence the FDI patterns. Further, we are interested in the way foreign direct investments shape the economy.

(C) 2016 Apostolov. This article is distributed under the terms of the Creative Commons Attribution 4.0 International License (http:// creativecommons.org/licenses/by/4.0/), which permits unrestricted use, distribution, and reproduction in any medium, provided you give appropriate credit to the original author(s) and the source, provide a link to the Creative Commons license, and indicate if changes were made. 
The basic hypothesis is that output depends on set of variables and is possibly driven by foreign ownership influx. In order to test this hypothesis, it is used standard growth accounting approach, i.e., Cobb-Douglas production function, and more specifically two different ways are employed to see the effects. The first path is a regression used to see outcomes for every specific country separately. On the other hand, the second course of research examines the relationship of output to set of variables for the whole region of Southeast Europe.

The academic significance of the topic is in determining the factors that influence foreign direct investments, as well as the way FDI spillovers contribute toward the development of Southeast Europe transition economies.

In Sects. 2 and 3, we give the theoretical and literature framework and possible impact on the growth of the host country. Further, in Sect. 4 we form the analytical framework comprised of two main elements: (a) sample selection and data and (b) model and econometrics. Section 5 encompasses the results and effects, where we give simulations and answers to the research question. Finally, Sect. 5 tries to raise certain academic discussions and concludes.

\section{Theoretical and literature framework}

There are many studies that try to explain why multinational enterprises prefer foreign direct investment as instrument of setting up operations overseas, opposed to export or license. The most compelling arguments that come close to explication are those that relate the coexistence of proprietary knowledge and market failures in protecting that knowledge, where the firm through internalization of transactions guards its advances in technology, management know-how and brand (Caves 2007; Markusen 1995). Further, there is well-developed literature that examines the benefits of foreign direct investment on host-country economy. Transfer of technology to domestic companies, knowledge transfer, increased labor force productivity and decreased unemployment, and increased exports due to rectified competitive characteristics of companies can be counted as most noteworthy changes in a domestic economy due to increased foreign direct investment presence. The financial aspects on domestic balance of payments that fallow foreign direct investment include financing external current account deficits-a result of decreased capital spending and increased exports, non-debt-creating upshots, as well as increased income on behalf of overall capital and product transactions and, finally, increased economic activity. When there is foreign direct investment in greenfield or brownfield plant, the firm that invests has anticipation of achieving a higher rate of return. Such expectations usually are a result of technological advantage and international foothold gained in global operations, strengthening the competitive advantage over the competition in sector or market. On the other hand, a domestic firm can have benefit from external influx of investment only in the case of indirect technology transfer in an environment where the international entrant is not willing voluntarily to give away its advantage. Therefore, present literature recognizes four channels through which the host might boost its productivity when interacting with foreign direct investment: (1) imitation, (2) skills acquisition, (3) competition and (4) exports. Host-country characteristics determine the intensity of spillovers where most dominant are those related to location, which define the decision on where to invest (Wheeler and Mody 1992; 
Brainard 1997). Another issue is the absorptive capacity of the host country to adopt new technology in order to harness productivity gains (Sánchez-Sellero et al. 2014).

However, foreign direct investments have been received with mixed blessing. Negative outcomes have been frequently attributed to the fact that foreign firms reduce the productivity of domestic firms through competition effects (Aitken and Harrison 1999; Konings 2001). Without a doubt, internationally established firms retain lower marginal costs because of firm-specific advantage, which permits them to attract demand away from domestic firms, pressing them to reduce production and move up their average cost curve. The presence of highly competitive international players on weak domestic markets often leads to market abuse followed by reluctant political pressures. Further, large investors more often than not coax concessions from host-country governments on top of transfer pricing used to maximize tax obligations, hence encouraging volatile balance of payment flows. There are other potential negative outcomes related to number of countries and most often tied to horizontal spillovers (Blomström and Sjöholm 1999; Monastiriotis and Alegria 2011; Acemoglu et al. 2010; Keller and Yeaple 2009; Aitken and Harrison 1999; Castellani and Zanfei 2007; Djankov and Hoekman 2000).

Indeed, it can be said that overall, the literature has settled on a broad consensus that the benefits of FDI tend to considerably outweigh its costs for host countries and companies. There are good surveys on the general effects of FDI (Borensztein et al. 1998; Lim 2001), diffusion of innovation and productivity effects (Javorcik 2004; Smarzynska Javorcik 2004; Javorcik and Spatareanu 2011) and theoretical summaries of policy implications related to sizeable capital inflows (Lane et al. 2002). The evidence related to horizontal effects is weaker; nonetheless, there are studies that confirm the presence of positive spillovers in aggregate (for UK (Liu et al. 2000; Haskel et al. 2007), for Ireland (Görg and Strobl 2003a, b), for USA (Keller and Yeaple 2009), for number of transition countries (Damijan et al. 2013). Transition economies have evident that capital need because of continuous enterprise restructuring and potential benefits of fresh capital, mainly due to inflow of FDI, is critically important. As such economies have highly educated labor force; another important dimension is transfer of specific knowledge, knowhow and technology that FDIs bring to the domestic economy and influence local firms' competitiveness. Non-debt-creating agenda is highly imposed in restricted capital conditions, and FDIs are used as life support of fresh capital (Frankel and Rose 1996; Apostolov 2013b).

Effects can be caused in number of ways. Host country can improve its domestic base by using processes purchased from large international companies (licenses, franchises, etc.), or local companies can obtain such knowledge by reverse engineering. Additionally, foreign firms employ local stuff on management and labor positions, which gain experience and process knowledge that will eventually be transferred to domestic companies and start-ups. And, finally, the change in competitive structure pushes domestic companies to adapt and employ all necessary business systems in order to stay in the game (Glass and Saggi 2002).

\subsection{Policy environment}

Economic and enterprise restructuring in Central Europe attributed significantly toward transition theory and practice, and especially to the fact that large amounts of foreign 
direct investment, at early stage, generate positive economic and political change. Thus, as such model was derived; it became much desired and, in fact, advised for implementation in Southeast Europe. So, significant inflows of foreign direct investment were attracted due to policy changes and agile marketing tactics of every country in Southeast Europe; as a consequence, as the competition between them increases, it is likely to catalyze higher value-added inflows.

The policy environment in Southeast Europe has improved over the years, while all counties have successfully tackled inflation, developed noteworthy private sector through deregulation and privatization. Other important changes fallowed with improved business environment and slimmed-down public administration. Increased competitive characteristics meant reduced overall tax rates, and as a trade-off, they instigated foreign direct investments to balance current account deficits. Certainly, such policies set foreign direct investments on pedestal, as all other policies must be in sync with the aim of attracting fresh capital in form of FDI.

On the other hand, there are numerous weaknesses in number of areas. Feeble spots lay in corruption, law enforcement, property rights protection, i.e., generally in governance. In economic terms, major flows surfaced during the euro-area recession as most important trading partner of Southeast European countries are those of the European Union. So, these economies suffered imported chain reaction on their already weak bases. Nonetheless, Southeast European countries have accepted, more or less, a general approach to shaping the investment environment (Fig. 1) (Liebscher 2005). Such policies gave beneficial effects in determining FDI flows.

\subsection{Timeline of effects of foreign investment on domestic firms}

It has been found that the effects of foreign direct investment are dynamic (Merlevede et al. 2014). In fact, host economy benefits from presence of majority foreign-owned companies, and it depends on the time of presence of the foreign entrant into domestic market, hence the longer-the better. The literature gives general guidelines on negative (horizontal) effects, but it is usually explained on short-term bases and damaged competitive characteristics of domestic companies. When only the impact of entry is analyzed, the results show that there are only modest outcomes. However, most that benefit from immediate foreign entry are local suppliers, and thus within first few years of entry, local suppliers have considerable growth because of enhanced business relations with the majority foreign-owned companies. As time goes by, the effects become lighter.

- unifying FDI registration and approval procedures with those for domestic firms;

- allowing acquisition of real estate by foreign investors for FDI purposes;

- minimizing FDI-related requirements on statistical reporting, work and residence permits;

- eliminating discrimination in access to government procurement contracts; and

- removing obstacles to FDI in financial and professional services.

Fig. 1 General characteristics on investment reform in Southeast Europe 
Nonetheless, post-entry effects last longer and it is due to increased competitive characteristics of domestic cooperants and newly formed start-ups (Xu and Sheng 2012).

Overall impression is that there is strong positive effect from foreign direct investment, and if it is to be harnessed, it needs time. Effects on local suppliers are defined by the time of entry and are immediate and positive. In the next few years, the effect fades and it is attributed to horizontal spillovers. The time after that or longer presence of foreign direct investments is followed by increased strength of domestic companies that adopt to changing market conditions (Fig. 2).

\subsection{Efficiency effects}

When it comes to establishing efficiency effects from foreign direct investment, the literature gives two general outcomes: (1) horizontal or inter-industry effects and (2) vertical or intra-industry effects.

\subsubsection{Horizontal/inter-industry effects}

The inter-industry effects are usually negative effects from foreign direct investment that disturb the market and force domestic companies out of business due to their dominant position. Hence, important studies claiming negative productivity effects on domestic companies are (Aitken and Harrison 1999) (study on Venezuela) (Kathuria 2000) (study on India). Foreign internationals operating on local markets have tendency to keep technology leaks using patents and high wages to critical employees. FDIs normally function in well-established surroundings where encircle themselves only with trusted suppliers, thus preventing potential domestic players from entering into their business (Kokko 1994).

Horizontal effects are crucial when it comes to building dominant position while precluding competition on domestic sector markets and draining domestic market of quality labor. This increases costs for local companies making them likely to exit the market (Aitken and Harrison 1999).

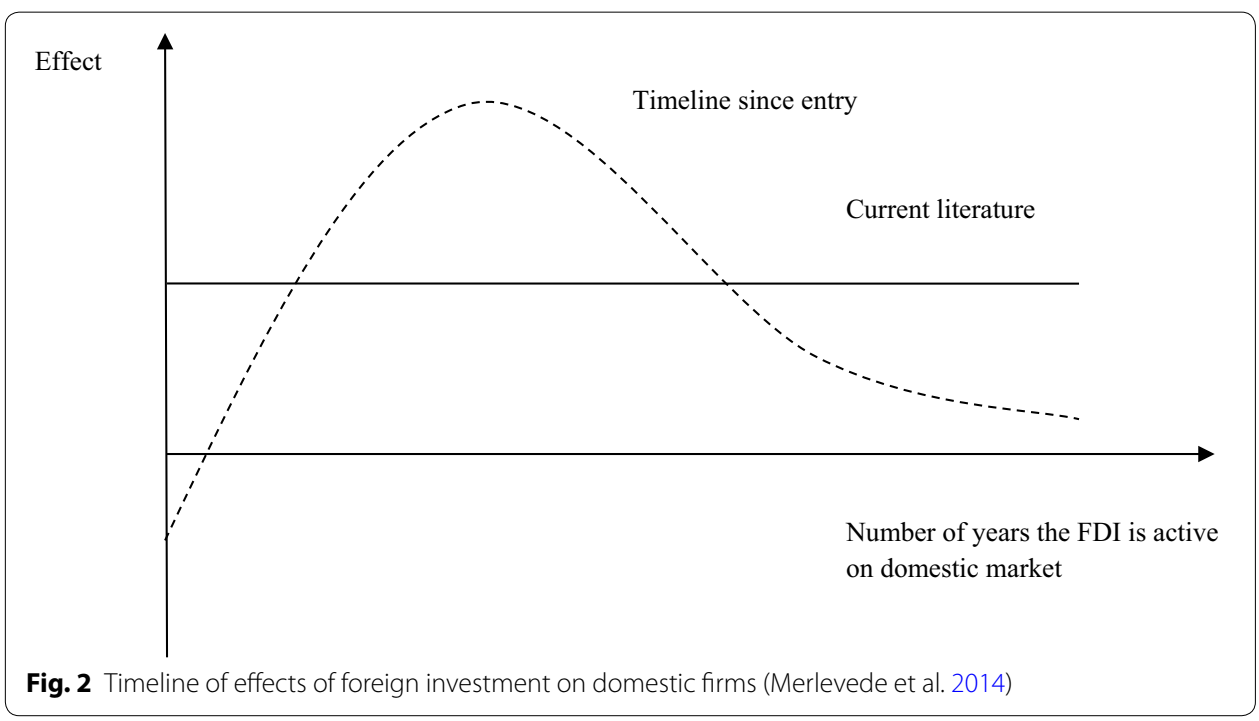


Negative results can be caused also vertically when the market is distorted and foreign direct investment externalities influence supply chains of domestic companies, tightening productivity gains and profit levels, which is translated in loss of competitive advantage to domestic enterprises (Beugelsdijk et al. 2008).

\subsubsection{Vertical/intra-industry effects}

Intra-industry or vertical effects are upstream and downstream productivity gains for domestic companies. The case of positive effects consists of increased business standards applied by suppliers in the beginning phase and increased competitive characteristics of domestic companies overall. Thus far, the literature gives proof of significant technology transfer to the affiliates generating positive spillovers to domestic firms or/ and such effects are limited to certain industries (Aitken and Harrison 1999; Haddad and Harrison 1993). It is estimated that these effects can be quite substantial (Smarzynska Javorcik 2004; Barrios et al. 2011) (study on UK) (Haskel et al. 2007) (study on US) (Keller and Yeaple 2009).

Important effects can be noticed in production design practices as well as know-how transfer that eventually impact managerial practices and overall corporate governance of local enterprises (Tan and Meyer 2010; Filatotchev et al. 2007; Vera-Cruz and Dutrénit 2005). The interaction with foreign managers and top practices increase the level of available knowledge to all local employees. Due time, it makes local managers more apt to work and transfer such techniques further downstream, strengthening the supply chain of the present foreign investment and supplier domestic companies. Such local companies are later capable of undertaking more competitive approach to the same or other markets increasing productivity, allowing them access to foreign markets (Girma et al. 2008; La Porta and Shleifer 2014).

The most noticeable direct form of positive effects can be found in the cooperation with domestic suppliers. However, indirectly there is increased domestic productivity, economies of scale of domestic companies, availability of technological goods and imitation and employment (Blalock and Gertler 2008). In other words, technology spillovers from foreign-owned firms tend to take place more frequently when the absorptive capacity of firms and the social capabilities of the host country are both high. Foreign direct investments and presence of foreign capital can be considered positive even if there are no spillovers. Such peculiarity is characteristic for economies in transition, where foreign capital has crucial role in overall enterprise restructuring (Blanchard 1998; Djankov and Murrell 2002; Apostolov 2013a).

\subsection{Absorptive capacity}

It is evident that not all firms are likely to gain from foreign presence and equally share knowledge/technology spillovers. The degree of benefit assimilation will depend on the absorptive capacity for adapting knowledge. The basic idea is that effects will depend on complexity the technology introduced by the foreign entrant and the technology gap between domestic and foreign-owned firms (Kokko 1994; Girma 2005b). Further, an extension of that idea is the hypothesis that domestic firms can only benefit if the technology gap is not too broad (Blomström et al. 1994; Glass and Saggi 1998). It is required 
some level of absorptive capacity so that domestic firms can benefit from productivity effects generated by foreign direct investments (Girma 2005a, Fu 2008).

\section{Growth of the host country}

The basic reason for examining spillovers from foreign-owned to domestically owned firms is to grasp the involvement of inward foreign direct investment to host-country economic growth. Foreign firms generally have higher productivity than local firms, but the evidence on spillovers to local firms' productivity is mixed. It seems that it depends on host-country policies and the technological absorptive capacity of domestic firms. Increased productivity of foreign companies is expected to have positive influence on domestic firms towing them to another level of development. However, if such higher productivity of foreign-owned firms is achieved at the expense of lower productivity of domestic firms, the effect on aggregate output (growth) is to be negative (competition argument). Growth effects can exist even devoid of spillovers, and usually they occur as a consequence of the operations of the foreign firms themselves; nonetheless, such possibility is hardly ever investigated and usually implied in studies exploring the impact of the entrance/growth of foreign firms on the output/growth of a host country. As far as evidence is concerned, there is proof of positive impact of inward foreign direct investments in the case of developing economies, where it is noted that the main obstacle is not the physical capital but rather the gap in knowledge (Blomström and Kokko 1998). In such cases, much of the driving force of the host economy is the human or organizational capital of foreign firms, and thus, for more vigorous growth a country has to implement policies that give foreign firms an incentive to close the technological gap while making profit on the way, as well as by crafting favorable business environment that offers an ample return to foreign firms, letting them convey ideas from the rest of the world while employing domestic resources.

The effects of foreign direct investment usually have been studied through comprehensive cross-country studies that take the rate of growth of real gross domestic product (or gross domestic product per capita) and tie it to the stock or inflow of foreign direct investments. By and large, the results of these studies point to the fact that the size of foreign direct investments flows, relative to gross domestic product, is not linked in any reliable aspect to rates of growth. Nevertheless, the majority of studies find that among some subsets of the host economy, foreign direct investments do have strong positive influence on economic growth. While analyzing developing economies, there are proven positive links between foreign direct investment and growth (a study of developing economies for the period 1960-1985) (Girma et al. 2001). Anyhow, when a study on developing economies was done separating the higher-income from lower-income countries, the results gave different turns, i.e., foreign direct investment encouraged growth only in the higher-income countries (a study on 69 developing countries from 1970-1989 found when foreign direct investment interacted with the level of education shaping the labor force, and thus being a considerable positive influence) (Borensztein et al. 1998). The same relationship was confirmed in later research (Aitken et al. 1997). There are diverse explanations regarding growth effects of inward foreign direct investments one of which that has most ground is that the effect depends on introduced policies of the host country. Therefore, the efficiency of foreign direct investment could be increased by an export 
promotion policy or decreased by an import substitution policy (Balasubramanyam et al. 1996). Another rationalization related to effects of foreign direct investments is the existence and extent of local financial markets, which is taken as essential determinant shaping of the way growth might transpire (Alfaro et al. 2004). The basic argument in absence or weakness of local financial markets is that domestic firms are devastated by uneasy access to finance and thus are unable to take benefit of the variation of know-how that is disposable to them introduced by the foreign firms (Dosi and Soete 1983). Other studies on both developing and developed economies find significant effect of foreign direct investment inflows; however, more important fact is that none of the variables found in most of the studies exactly determine the effect of foreign direct investment on growth. On the other hand, when the approach contains a narrower group of countries, especially transition economies, it can be observed that foreign direct investment is crucial explanatory variable for growth (Hubert and Pain 2001). It must be said that the literature still does not have conclusive stands on the effects of foreign direct investments on economic growth, as it is also the case with studies on wage and productivity spillovers. The impact of foreign direct investment in promoting growth of host-country exports/ linkages to the outside world is clearer. The major role of foreign direct investment in the transformation of host economies from being exporters of raw materials and foods to being exporters of manufactured goods, and in some cases relatively high-tech products, is too evident in some cases. Much of the impact is from the transfer of knowledge and of ways of fitting into worldwide production networks, not visible in standard productivity measurements. Thus, most of the studies find positive effects for periods of time or some groups of countries, but it cannot be claimed that these are common effects. Indeed, there are countries, periods and sectors where foreign direct investments have significantly positive influence and relation to economic growth; however, it is always conditioned by specific factors detailed in the analysis in question.

\section{Analytical framework}

\subsection{Sample selection and data}

The data used in this research are from Enterprise Surveys data sets specified by the World Bank Microdata Library. These surveys are firm-level representative samples that gather information from the economy's private sector. Further, the data sets include a wide variety of business environment topics including firm characteristics, gender participation, access to finance, annual sales, costs of inputs/labor, workforce composition, bribery, licensing, infrastructure, trade, crime, competition, capacity utilization, land and permits, taxation, informality, business-government relations, innovation and technology, and performance measures. The data sets can be individual and country specific, as well as aggregated throughout the years in order to give relevant information to the public. Hence, the questions are addressed to business owners and top managers, normally 1200-1800 interviews in larger economies, 360 interviews in medium-sized economies and 150 interviews in smaller economies. The surveys are derived through two instruments: the Manufacturing Questionnaire and the Services Questionnaire. ${ }^{1}$

${ }^{1}$ Enterprise Surveys-World Bank Microdata Library, available at: (http://www.enterprisesurveys.org/). 
For purpose of this research, we use specifically separated data sets contained in the World Bank's Enterprise Surveys, which will help us to formulate answers to the possibilities of spillover effect. Hence, we utilize the number of permanent full-time workers, capacity utilization (\%), annual employment growth (\%), annual labor productivity growth (\%), proportion of total sales that are exported directly (\%) and proportion of total sales that are exported indirectly (\%), in order to see whether the proportion of private foreign ownership in a firm (\%) is the effect.

Definition of used variables (World Bank 2015):

- Proportion of private foreign ownership in a firm (\%) - percentage of the firm owned by foreign individuals, companies or organizations (FDI);

- Number of permanent full-time workers-number of permanent full-time workers employed in the current fiscal year (FTW);

- Capacity utilization (\%)-capacity utilization based on comparison of the current output with the maximum output possible using the current inputs by firms (CU);

- Annual employment growth (\%)-annual employment growth is the change in fulltime employment reported in the current fiscal year from a previous period (AEG);

- Annual labor productivity growth (\%)-annualized growth in labor productivity where labor productivity is real sales (using GDP deflators) divided by full-time permanent workers (ALPG);

- Proportion of total sales that are exported directly (\%) - sales exported directly as percentage of total sales (PTSExD);

- Proportion of total sales that are exported indirectly (\%)-sales exported indirectly as percentage of total sales (PTSExI).

Additionally, due to regression analysis we can read the causes that are involved in the change in economy's ownership structure or the effect translated in private foreign ownership. The sample data are well drawn and can be used purposely (Tables 1, 2).

\subsection{Model and econometrics}

In this analysis, we use standard growth accounting approach which is a breakdown of observed economic growth into components related to changes in factor inputs, a residual that reflects progress and other elements (Barro 1998). In this subsection, we estimate the impact of external sources, on the growth of Southeast European economies and firms. The basics of growth accounting were presented by Solow (Solow 1957); however, over time there were important advancements of this model (Kendrick 1961; Denison 1962; Jorgenson and Griliches 1967). As analytical framework of this research, we take economy where progress is dependent on 'capital deepening' in form of increased capital goods available (Romer 1990; Barro and Sala-i-Martin 1997). We use standard Cobb-Douglas production function:

$$
Y_{t}=a L_{t}^{b} C_{t}^{c}
$$

where $Y$ is output; $L$ stands for human capital (labor); $C$ represents physical capital; and the parameters $a, b$ and $c$ (the latter two being the exponents) are estimated from empirical data. Consequently, the state of environment includes policy issues controlling 
Table 1 Summary statistics on the regression model

\begin{tabular}{|c|c|c|c|c|c|c|c|c|}
\hline & \multicolumn{8}{|c|}{ Summary statistics } \\
\hline & Mean & Std. dev. & Min & Max & Mean & Std. dev. & Min & Max \\
\hline & \multicolumn{4}{|l|}{ Albania } & \multicolumn{4}{|c|}{ Bosnia and Herzegovina } \\
\hline Output & 4.11 & 2.148303 & 1.4 & 5.9 & 1.642373 & 3.339017 & -2.9 & 5.3 \\
\hline FDI & 15.80851 & 19.62684 & 0 & 88.2 & 11.78983 & 18.39724 & 0 & 81.2 \\
\hline FTW & 3.303447 & 0.802159 & 2.014903 & 5.374352 & 3.948834 & 0.829736 & 2.054124 & 5.773309 \\
\hline $\mathrm{CU}$ & 74.41538 & 5.513741 & 61.1 & 92.7 & 76.89245 & 5.671821 & 53.9 & 88.2 \\
\hline AEG & 9.085714 & 6.495794 & 0.5 & 18.6 & 3.494595 & 2.841845 & -1.9 & 12.1 \\
\hline ALPG & -2.03182 & 6.108884 & -9.3 & 12.5 & 5.235294 & 3.922421 & -4.7 & 19 \\
\hline PTSEXD & 15.48085 & 16.67517 & 0 & 62.6 & 14.08136 & 12.02102 & 0.2 & 57.8 \\
\hline \multirow[t]{2}{*}{ PTSExl } & 3.07234 & 3.54442 & 0.4 & 24.1 & 1.888136 & 1.401857 & 0 & 5.4 \\
\hline & \multicolumn{4}{|l|}{ Croatia } & \multicolumn{4}{|l|}{ Macedonia } \\
\hline Output & 3.003333 & 2.611121 & -0.9 & 5.2 & 1.353448 & 2.298681 & -1.6 & 4.1 \\
\hline FDI & 13.06333 & 19.75107 & 0 & 86.2 & 12.20862 & 17.71655 & 0 & 84.9 \\
\hline FTW & 4.010516 & 1.065431 & 1.960095 & 6.647688 & 3.650884 & 1.139481 & 1.902107 & 6.29545 \\
\hline $\mathrm{CU}$ & 78.3963 & 5.342883 & 65.4 & 90.2 & 76.45882 & 5.419416 & 63.2 & 89.8 \\
\hline AEG & 5.041026 & 3.360037 & 0 & 19.4 & 9.563889 & 2.202227 & 5 & 14.3 \\
\hline ALPG & -0.8 & 9.590029 & -20.5 & 31.3 & 1.974286 & 4.055305 & -5.7 & 12.3 \\
\hline PTSExD & 15.05333 & 12.16701 & 0.3 & 50.3 & 16.27931 & 14.31342 & 0.1 & 62.3 \\
\hline \multirow[t]{2}{*}{ PTSExI } & 3.051667 & 2.523079 & 0 & 13.6 & 6.394828 & 5.319426 & 0.1 & 20.9 \\
\hline & \multicolumn{4}{|l|}{ Serbia } & \multicolumn{4}{|l|}{ Slovenia } \\
\hline Output & 1.838333 & 3.978931 & -3.1 & 7.1 & -1.29445 & 4.879623 & -7.8 & 4 \\
\hline FDI & 13.22667 & 19.66332 & 0 & 83.8 & 16.14259 & 21.29529 & 0 & 99 \\
\hline FTW & 3.997069 & 1.014015 & 2.014903 & 6.2293 & 3.837273 & 1.046518 & 1.987874 & 6.0965 \\
\hline $\mathrm{CU}$ & 72.07547 & 7.056282 & 52.5 & 85.6 & 80.8125 & 6.289763 & 63.8 & 88.1 \\
\hline AEG & 4.028947 & 2.937632 & -2.9 & 12.8 & 2.170588 & 3.202038 & -3.3 & 10.7 \\
\hline ALPG & 8.008108 & 4.594041 & -1.1 & 21.1 & 6.275 & 3.422789 & 0.4 & 20.4 \\
\hline PTSExD & 11.68833 & 8.180819 & 0.4 & 47.8 & 23.44444 & 15.729 & 0.5 & 57.5 \\
\hline PTSExI & 1.906667 & 1.310307 & 0.1 & 6.6 & 3.266667 & 2.215298 & 0 & 11 \\
\hline
\end{tabular}

Table 2 Summary statistics on the fixed effects model

\begin{tabular}{|c|c|c|c|c|}
\hline & \multicolumn{4}{|c|}{ Summary statistics } \\
\hline & \multicolumn{4}{|c|}{ Southeast Europe } \\
\hline & Mean & Std. dev. & Min & Max \\
\hline Output & 1.76393 & 3.700448 & -7.8 & 7.1 \\
\hline $\mathrm{FDI}$ & 13.59704 & 19.33725 & 0 & 99 \\
\hline FTW & 3.838126 & 1.020154 & 1.902107 & 6.647688 \\
\hline $\mathrm{Cu}$ & 76.54128 & 6.50296 & 52.5 & 92.7 \\
\hline AEG & 5.431604 & 4.491233 & -3.3 & 19.4 \\
\hline ALPG & 3.379293 & 6.733334 & -20.5 & 31.3 \\
\hline PTSEXD & 15.89675 & 13.67681 & 0 & 62.6 \\
\hline PTSEx| & 3.256213 & 3.37424 & 0 & 24.1 \\
\hline
\end{tabular}

the level of productivity in the economy. Physical capital is sum of different varieties of capital goods, and hence, capital accumulation is of essence when it comes to rapid development. 
In economics, a 'production function' describes an empirical relationship between specified output and inputs. A production function can be used to represent output production for a single firm, for an industry, or for a nation.

In most applications of production functions, the input variables are simply labor $(L)$ and capital $(C)$. It is generally assumed that a production function, $F(L, C)$, satisfies the following properties:

- $F(L, 0)=0, F(0, C)=0$ (both factor inputs are required for output)

- $\mathrm{d} F / \mathrm{d} L>0, \mathrm{~d} F / \mathrm{d} C>0$ (an increase in either input increases output)

At a given set of inputs $(L, C)$, the production function may show decreasing, constant or increasing 'returns to scale':

- If $F(k L, k C)<k F(L, C)$, there are decreasing returns to scale

- If $\mathrm{F}(k L, k C)=k F(L, C)$, there are constant returns to scale

- If $\mathrm{F}(k L, k C)>k F(L, C)$, there are increasing returns to scale

Constant returns to scale imply that the total income from output production equals the total costs from inputs:

$$
p F(L, C)=w L+r C
$$

where $p$ is the price per unit output and $w$ and $r$ are costs of labor and capital.

Equivalent is a linear function of the logarithms of the three variables:

$$
\log (Y)=\log (a)+b \log (L)+c \log (C)
$$

If $b+c=1$, another equivalent form exhibits an underlying heuristic for the CobbDouglas model:

$$
\log (Y / L)=\log (a)+(1-b) \log (C / L)
$$

which says that the 'production per employee' $(Y / L)$ is a function of the capital investment per employee $(C / L)$.

Present literature mainly utilizes Cobb-Douglas production function in order to estimate effects on domestic enterprises, or more precisely domestic firm productivity (Aitken and Harrison 1999; Blalock and Gertler 2008). Following this function, we take the variables: (1) exogenous state of environment closely related to capital-proportion of private foreign ownership in a firm (\%), capacity utilization (\%); (2) labor-number of permanent full-time workers, annual employment growth (\%), annual labor productivity growth (\%); (3) direct and indirect effects of physical capital-proportion of total sales that are exported directly (\%) and proportion of total sales that are exported indirectly (\%).

In order to work with the variables, we take linear function of the logarithms to calculate approximately the unknown parameters. The model has proven over time to give stable results, and it is widely used. The dependent variable stands for output, or in this case it is tested to see whether it is the effect. Further, the independent variables are inputs, and they are investigated to clarify whether they are the cause. 
1st The Regression

The first econometric model that is used in this study is a basic regression model (Freedman 2005; Freedman et al. 2007). Thus, applied to our research this model has the fallowing shape:

$$
\begin{aligned}
\log Y_{i, t}= & \beta_{0}+\beta_{1} F D I_{i, t}+\beta_{2} \log F T W_{i, t}+\beta_{3} C U_{i, t}+\beta_{4} A E G_{i, t}+\beta_{5} A L P G_{i, t} \\
& +\beta_{6} \operatorname{PTSExD}_{i, t}+\beta_{7} \operatorname{PTSExI}_{i, t}+\varepsilon_{i, t}
\end{aligned}
$$

2nd The Fixed Effects Model

The second econometric model that is used in this study is fixed effects model to scrutinize the impact of variables that vary over time. By the use of fixed effects model, it is assumed that something may impact or bias the predictor or outcome variables, and thus such possibility is needed to be controlled. This model removes the effect of those time-invariant characteristics, so it can be assessed the net effect of the predictors on the outcome variable. The explanatory variables are treated as if the quantities were nonrandom which in panel data analysis gives time-independent effects (Wooldridge 2002, 2015). Applied in this study, this model takes the following form:

$$
\begin{aligned}
\log Y_{i, t}= & \beta_{o}+\beta_{1} F_{i, t}+\beta_{2} \log F_{i, W_{i, t}}+\beta_{3} C U_{i, t}+\beta_{4} A E G_{i, t}+\beta_{5} A L P G_{i, t} \\
& +\beta_{6} \operatorname{PTSExD}_{i, t}+\beta_{7} \text { PTSExI }_{i, t}+\alpha_{i}+u_{i, t}
\end{aligned}
$$

where the variables common for the first and second model are:

- the dependent variable, $Y_{i, t}$, is output;

- the independent variables are as follows:

1. $F D I_{i, t}$, proportion of private foreign ownership in a firm (\%)

2. $F T W_{i, t}$, number of permanent full-time workers;

3. $C U_{i, t}$, capacity utilization (\%);

4. $A E G_{i, t}$, annual employment growth (\%);

5. $A L P G_{i, t}$, annual labor productivity growth (\%);

6. PTSExD $D_{\mathrm{i}, \mathrm{t}}$, proportion of total sales that are exported directly (\%);

7. PTSExI $I_{\mathrm{i}, \mathrm{t}}$, proportion of total sales that are exported indirectly (\%);

- additionally, for the first model we have:

- $\beta$ is a $p$-dimensional parameter vector;

- $\varepsilon$ is the error term or noise.

- and for the second model:

- $\alpha_{i}(i=1, \ldots, n)$ is the unknown intercept for each entity (n entity-specific intercepts).

- $u_{i t}$ is the error term

N.B. capital is controlled for and the use of growth figures in a regression of levels through proxy variables, most notably private foreign ownership in a firm and capacity utilization. 


\section{Results and effects}

The results on the regression are presented in Tables 3, 4 and 5, as well as Figs. 3, 4 and 5. Thus, we take a combined approach to explaining the effects, where we use contents of both tables and figures. The basic hypothesis questions whether output depends on set of chosen variables: foreign proportion of private foreign ownership, number of permanent full-time workers; capacity utilization; annual employment growth; annual labor productivity growth; proportion of total sales that are exported directly and proportion of total sales that are exported indirectly. Every country is analyzed separately. In this research, we are mostly interested in the effects of foreign direct investment and its relation to overall economy.

In the case of Albania, the results (Table 3$)$ show strong positive inclination $(p<0.01)$ on annual employment growth and $(p<0.05)$ number of full-time workers. This is sign that the economy has been focused on assuming labor, and it is due to abundance of this particular factor of production (Lim 2001). Also, significance can be noticed on annual labor productivity growth, even though the proclivity is negative and can be interpreted in terms of labor-intensive allocation of capital and investments. On the other hand, however, there is offset on the proportion of total sales that are exported indirectly, where a significant negative result $(p<0.01)$ is noticed. This indicates that domestic companies are still not well included in production and exporting base, usually generated by foreign direct investments. In this regard, capacity utilization is seen to be positive (not significant), and it might indicate that there are new gains achieved by companies, but it must be said that this result has shown to be mixed and therefore speculative. Figure 3 confronts foreign direct investment and gross domestic product in a simple manner, and for Albania, it shows influx of FDI over time. The averages of FDI and GDP move closely in the first phases and nonetheless separate due time which is odd severance of these rather tied variables.

As far as Bosnia and Herzegovina is concerned (Table 3), there is a statistical significance in capacity utilization and annual employment growth $(p<0.01)$, inclined negatively. The decrease in annual employment growth can be explained through lag in permanent fill-time workers because of certain negative political movements that happened in the past few decades (Nastav and Bojnec 2007; Javorcik and Spatareanu 2011). Capacity utilization is indicator of capital use, and it shows unused capacities, unfortunately. Though, it can also be seen as advantage since there is space for increase in future employment of unused capacities. The constant illustrates that there is strong positive overall effect. When compared movements of gross domestic product and foreign direct investments (Fig. 3), we can notice that these two are closely related and interlinked.

Croatia has positive inclination on the number of full-time workers according to our analysis (Table 4), which can be interpreted as increased employment activity. More solid results are found on annual employment growth, where the statistical significance $(p<0.01)$ indicates employment sparked by influx of fresh capital (most notably from abroad) and preferably into capital-intensive sectors (Lane et al. 2002; Liebscher 2005). In the tests conducted for this country, we also find pessimistic movements of proportion of total sales that are exported indirectly $(p<0.01)$, a serious indication that domestic companies are lagging in creation of competitive output. Figure 4 shows general outlook of movements of gross domestic product and foreign direct investment for Croatia. It 


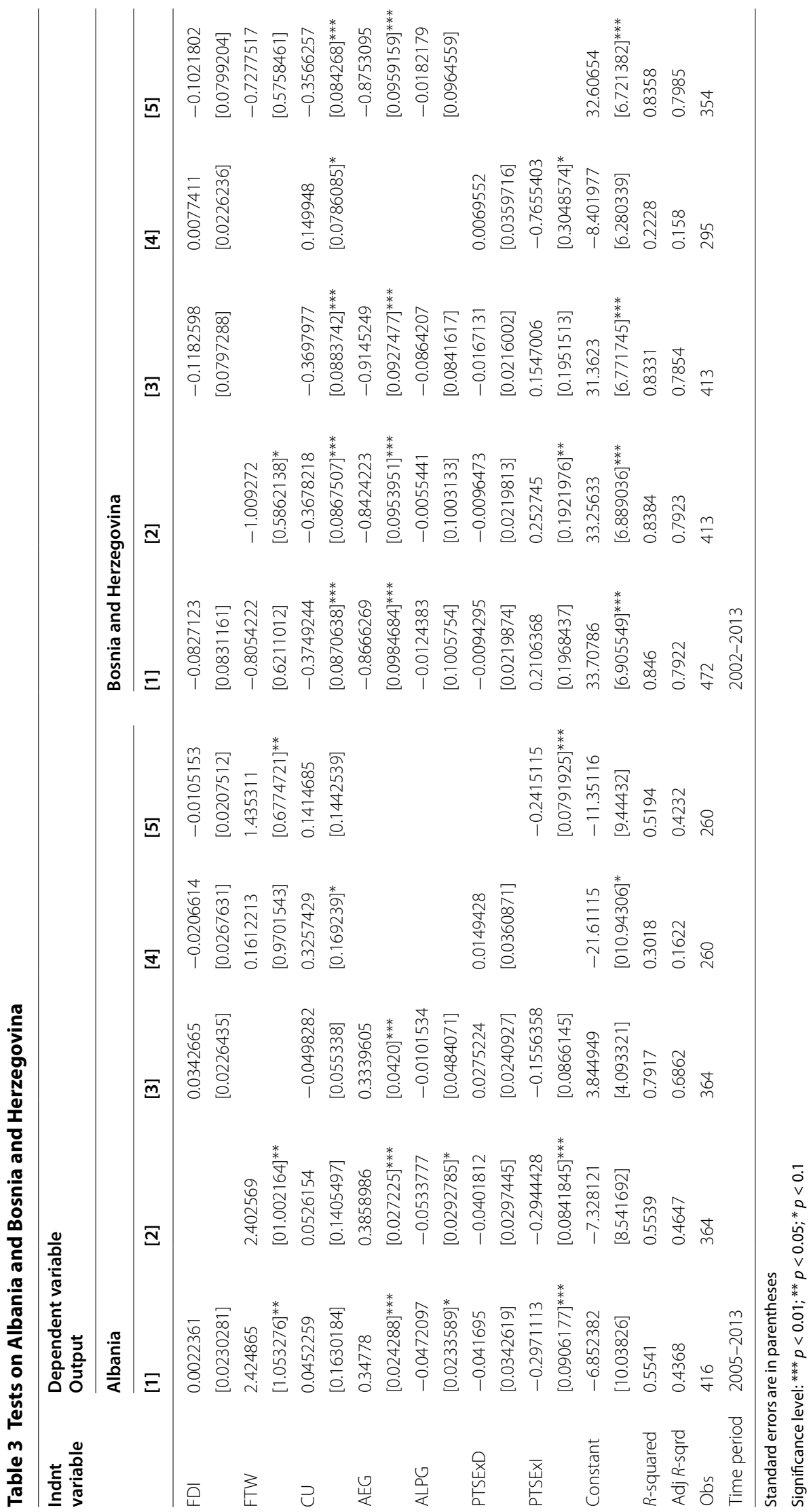




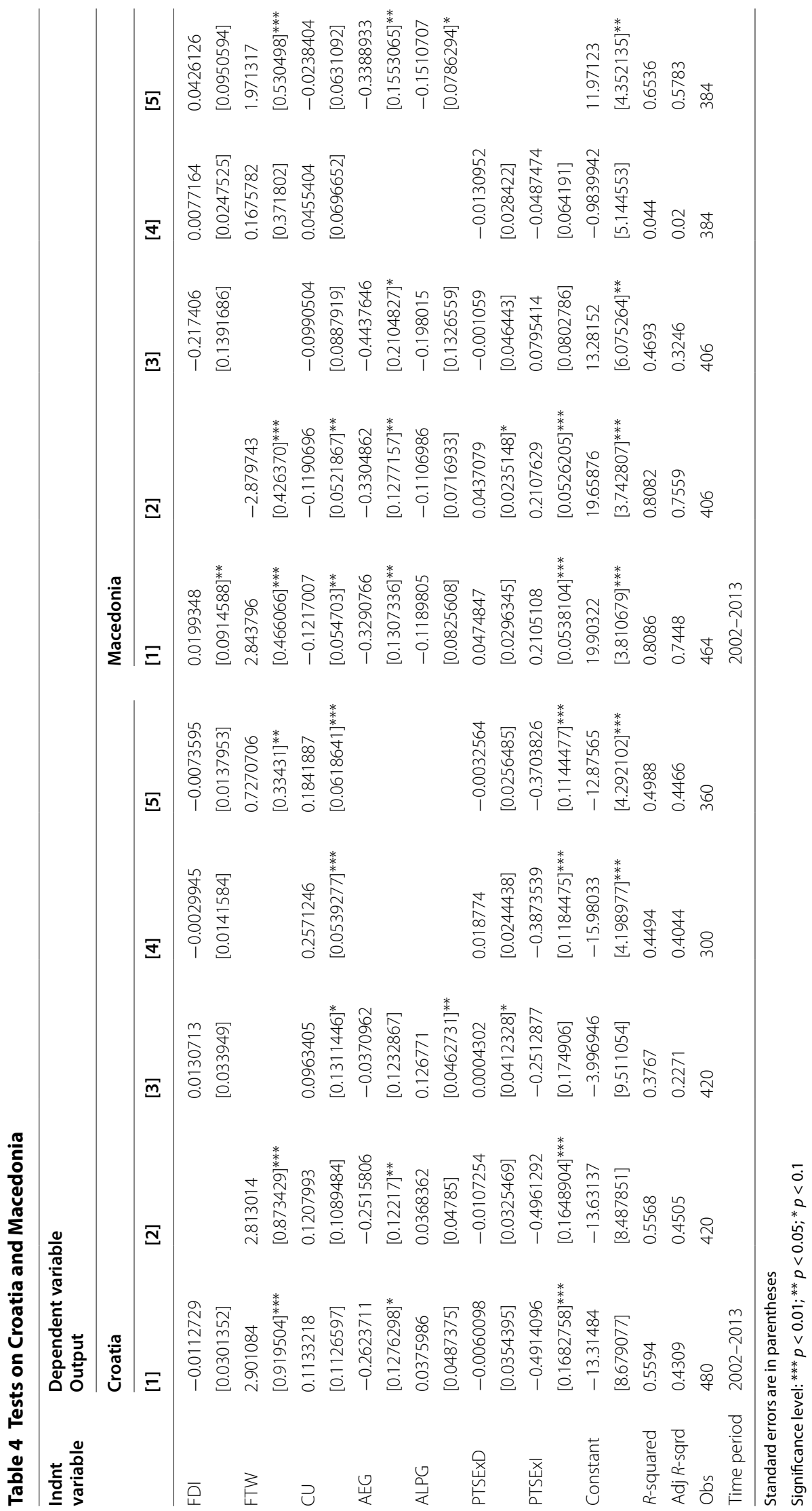




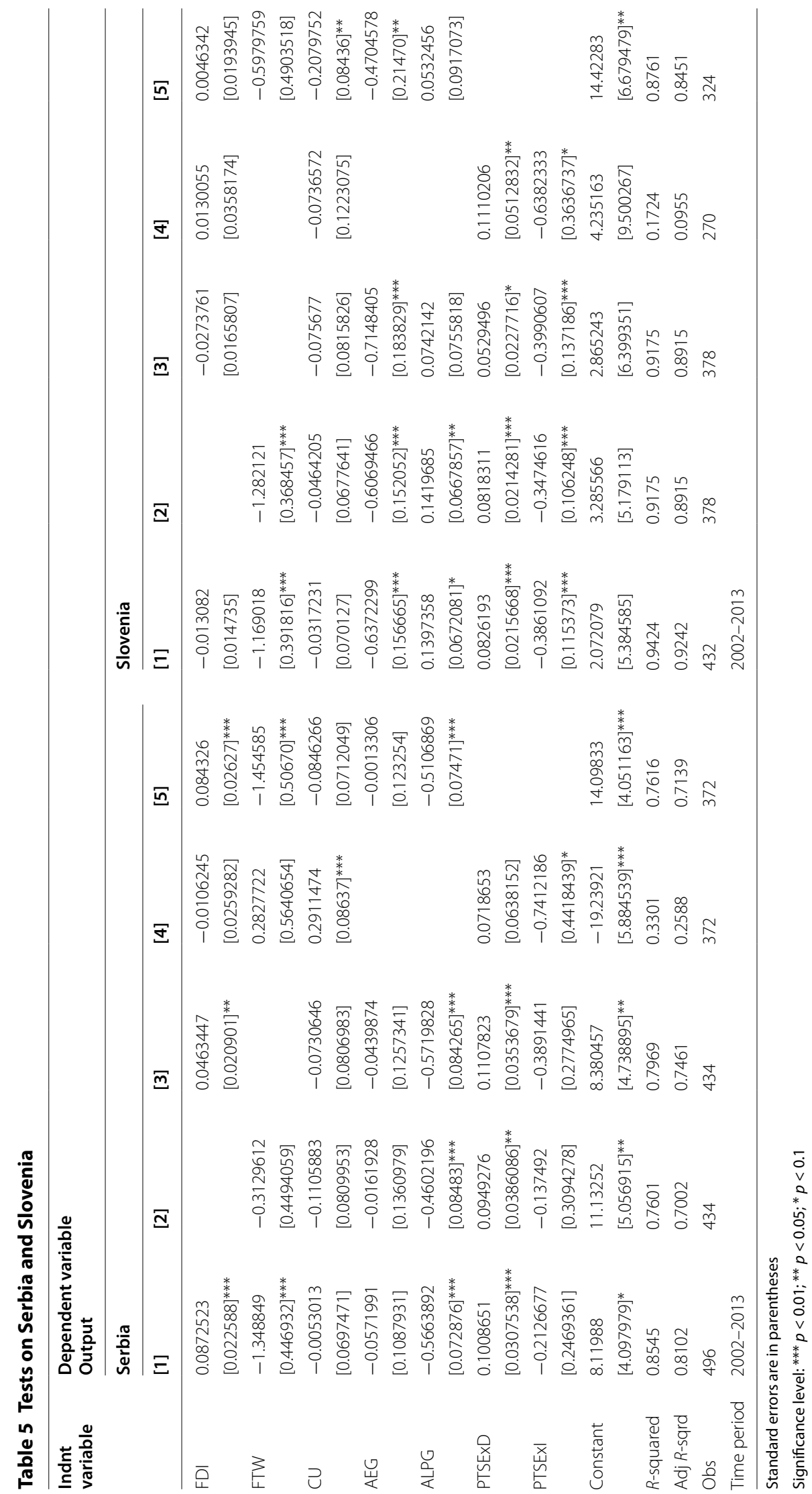



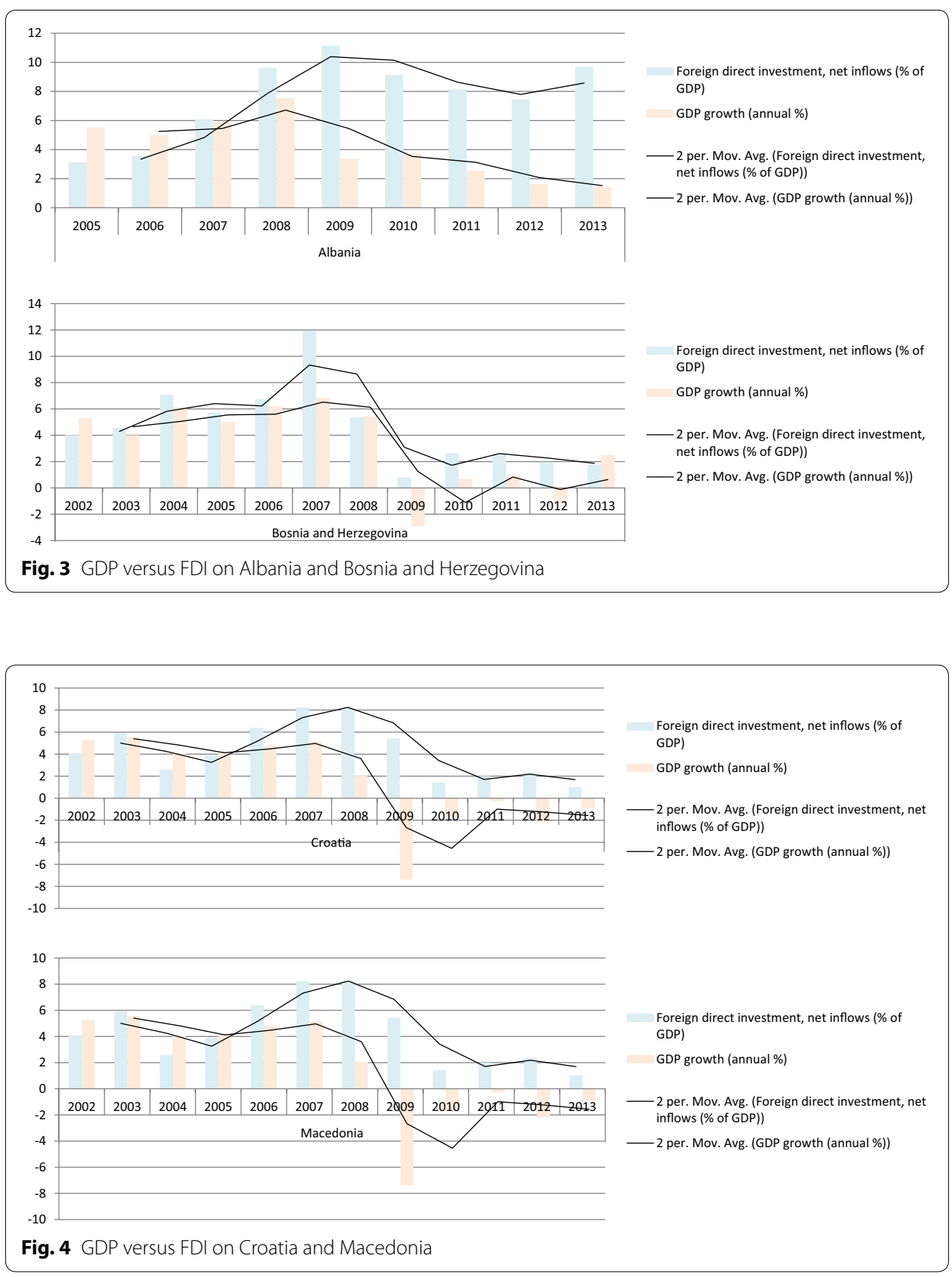

can be noticed that these two are in sync; nevertheless, foreign direct investment is more resilient to crises and always positive, driving the economy out of problems.

There are some interesting results on Macedonia (Table 4). Foreign ownership has proved to be positive influence on the overall output $(p<0.05)$; and the constant in most of the models is positive, significant and fairly high. We find significance with mixed sign for number of permanent full-time workers and negative inclination for capacity utilization, which points to the fact that the economy has capacities for employment that have not been reached in full yet and are inducing labor-intensive investments seen through reduced capacity utilization which eventually pressures domestic exports (La Porta and 


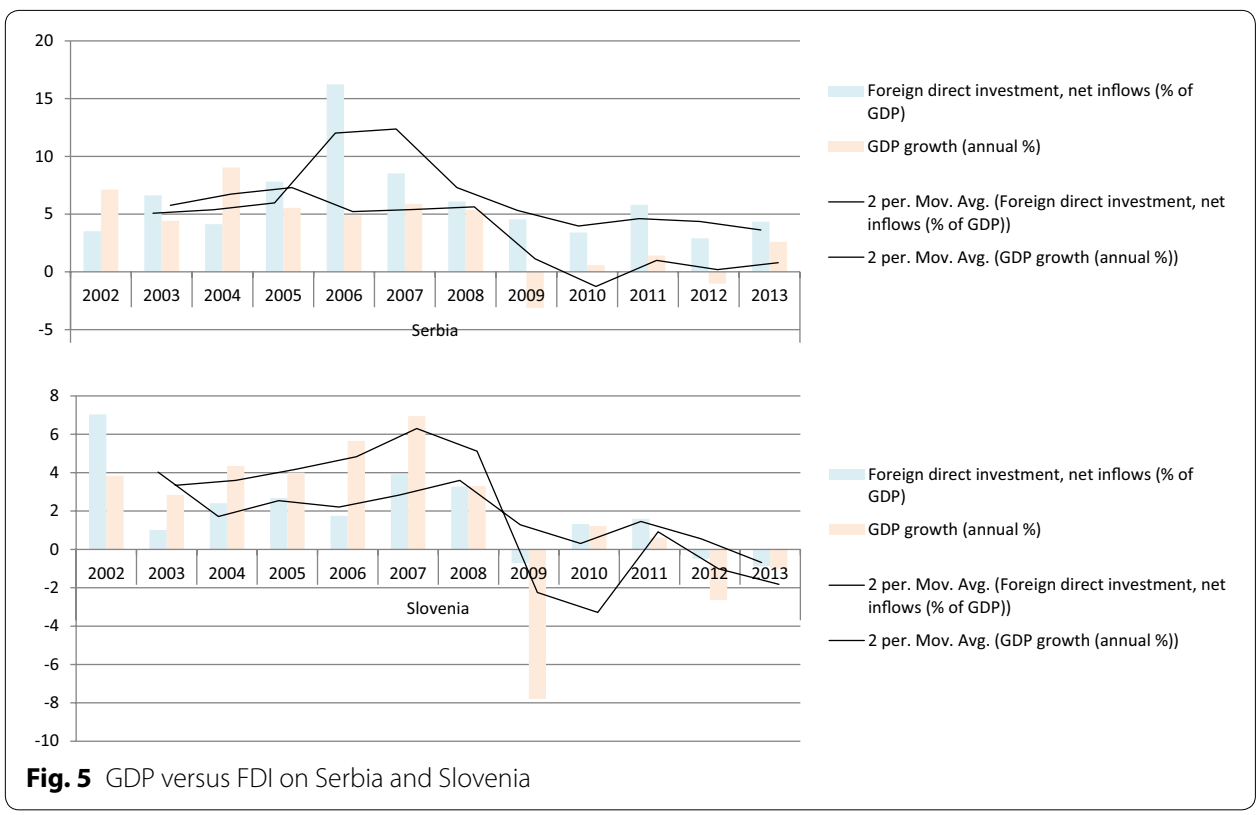

Shleifer 2014). On the other hand, proportion of total sales that are exported directly are with positive tendency which might as well be result of foreign ownership influx (Apostolov 2011). Indeed, this is consistent with the research on foreign direct investment links to countries' exports (Girma et al. 2008). Figure 4 shows that gross domestic product and foreign direct investments are closely tied. Without a doubt, it is evident that the influence of foreign direct investments is significant and contributes greatly overtaking the main indicator of the domestic economy.

Serbia is also a good example of foreign direct investment influence on domestic output (Table 5). There is positive significance related to foreign ownership $(p<0.01)$, which gives good grounds of the claim that foreign direct investment is major contribution to development of domestic economy. Further, it is also found that proportion of total sales that are exported directly are positive, that is, such occurrence is an effect of increased incursion of capital due to foreign direct investments (Djankov and Murrell 2002; Hanousek et al. 2011). Nevertheless, pessimistic outcomes were found for number of permanent full-time workers and annual labor productivity growth, falling in line with labor market developments in all other analyzed countries. These outcomes merit further explanation as it is the brightest case in this set of countries that has shown most impact of foreign ownership on output levels. Firstly, the inflows of foreign direct investment in this particular case have mostly been placed the tertiary sector of (banking, insurance, telecommunications and retail trade) and privatization of state-owned enterprises (Popov 2004, 2010). Secondly, there has been increase in number of number of export-oriented projects by foreign investors (most notable example is the investment of new plant by Fiat, SpA while shifting its production from Italy) (Trifunović et al. 2009) that have advanced domestic direct exports. Thirdly, unemployment is still lagging as in most of analyzed cases; nonetheless, increased investment and capital allocation will eventually reduce unemployment and improve the productivity structure of the labor market (Djankov and Hoekman 2000; Haskel et al. 2007). Finally, this country has had 
improvements in innovation and technology infrastructure owning to significant transfer of technology brought by foreign-owned firms (Cabrilo et al. 2009; Komnenic and Pokrajčić 2012), improved competition on domestic market and business environment. The relationship between gross domestic product and foreign direct investments (Fig. 5) follows the developments regionally. This means that these two are related and as output falls, foreign ownership is less inclined to invest in the country and, vice versa, foreign direct investments are general driver of domestic business opportunities. Also, the level of investment is quite high as there are unused economies of scale and possibilities for privatization of natural monopolies under way in this economy.

When analyzed Slovenia (Table 5), it is evident that this economy has fairly better quality of labor expressed through positive and increased annual labor productivity growth ( $p<0.1$ and $p<0.05$ depending on the model). Contrary, we see that there is fall of number of permanent full-time workers and negative annual employment growth which is mainly because of European debt crisis which hit Slovenia harshly and distorted the factor markets (Jaklič et al. 2014; Damijan et al. 2013). When investigated the exports, it is shown that there is positive significance in incline of proportion of total sales that are exported directly and it is owned mainly on capital-intensive sectors and foreign ownership, as the negative slope of proportion of total sales that are exported indirectly denotes less inclusion of domestic business in the output equation. Movements of gross domestic product and foreign direct investments (Fig. 5) are tied. The interesting thing about this case is that gross domestic product growth is found to be higher than the incursion of foreign ownership, and it is good indicator of endogenous path to growth. In the case of Slovenia, it can be said that it is far clearer that gross domestic product pulls foreign direct investment either way.

As far as the results on the fixed effects model are concerned, they are given in Table 6 and Figs. 6, 7, 8 and 9. To examine the basic hypothesis in this approach, it is used a whole set of countries, analyzed as a panel. The second model examines the relationship of output to set of variables for the whole region of Southeast Europe.

When analyzed the presence of foreign ownership scrutinized through proportion of private foreign ownership in a firm which is a percentage of the firm owned by foreign individuals, companies or organizations, we got mixed results that are unfortunately not conclusive. However, Fig. 9 shows positive inclinations for all variables used in this study. Also Fig. 8 indicates a potential positive relationship between output and foreign ownership and the incursion of foreign direct investments for the whole region.

The results on the number of permanent full-time workers or number of permanent full-time workers employed in the current fiscal year are also mixed with slight difference that there are positive outcomes and significance depending on the model and employed variables. It is evident that there is increase in the number of full-time workers (Figs. 8, 9) which is in relation to claims of current literature (Zhao 1998; Bailey and Driffield 2007; Aizenman 2003; Javorcik 2014).

We have found strong evidence for two variables: (1) capacity utilization (based on comparison of the current output with the maximum output possible using the current inputs by a firm) and (2) annual employment growth (the change in full-time employment reported in the current fiscal year from a previous period). Both of these two variables give negative results (Table 6) and hence can be claimed with certainly that there is 


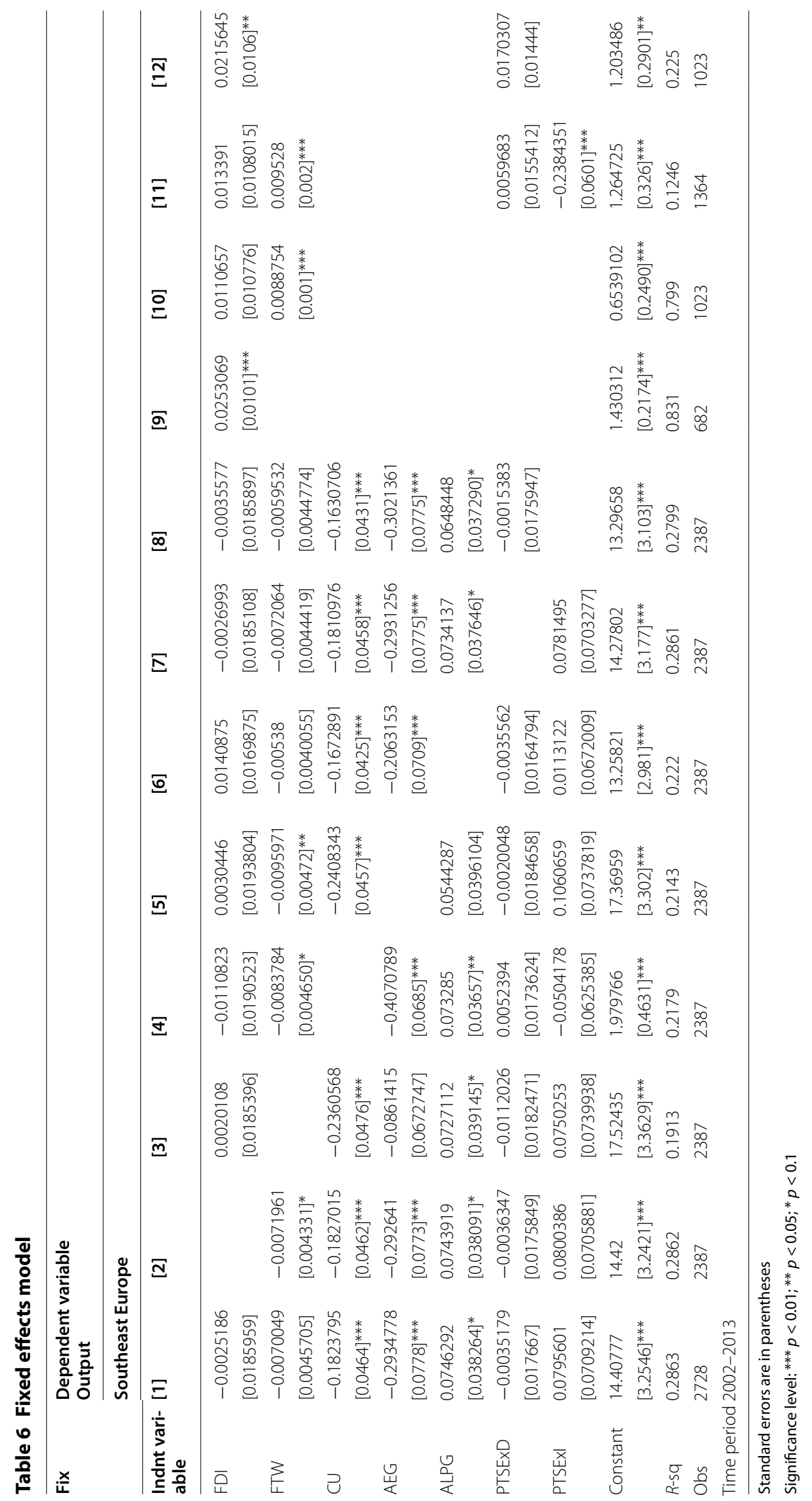



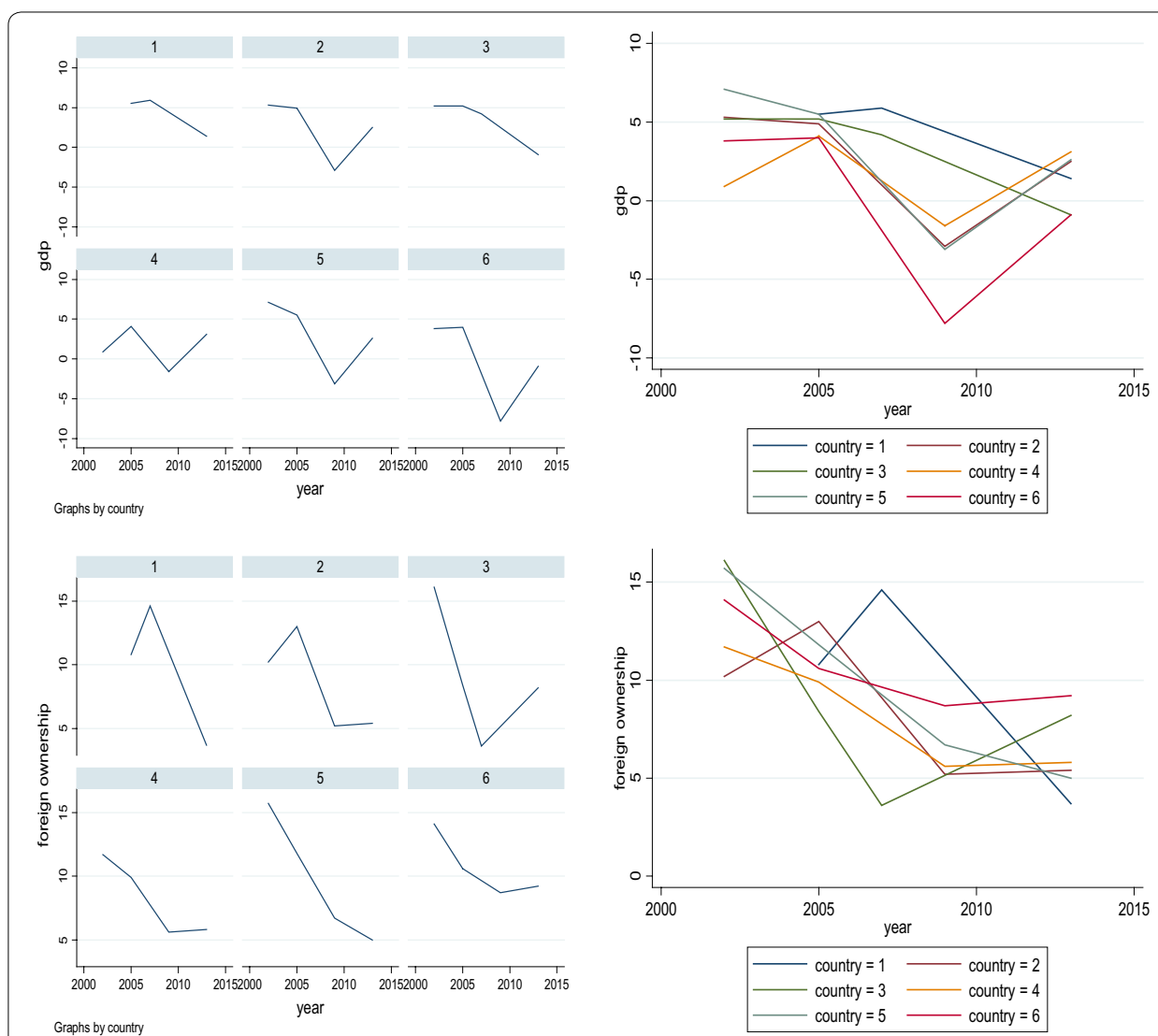

Fig. 6 Exploring panel data. N.B. countries: Albania (1), Bosnia and Herzegovina (2), Croatia (3), Macedonia (4), Serbia (5), Slovenia (6)

space for improvement of unused capacities of the firms, i.e., they have not yet reached their full potential. On the other hand, annual employment growth is lagging, which is consequence of historical postulates and disorderly politics encompassing this region.

For annual labor productivity growth (annualized growth in labor productivity where labor productivity is real sales (using GDP deflators) divided by full-time permanent workers), there is a significant and positive result (Table 6). Indeed, Fig. 9 shows good relation between annual labor productivity and foreign presence. Therefore, a policy recommendation would be that governments should aim for maximization of productivity benefits associated with foreign direct investments by assisting and encouraging local firms in becoming suppliers to foreign affiliates. (Javorcik 2014).

The variables used for proportion of total sales that are exported directly (sales exported directly as percentage of total sales) and proportion of total sales that are exported indirectly (sales exported indirectly as percentage of total sales) did not gave conclusive results. On the one hand, sales that are exported directly have good outlook when compared to output and foreign direct investments (Figs. 8, 9). On the other hand, sales that are exported indirectly have troublesome relationship with output and foreign direct investments, which is related to the gap between entry of foreign firm and engagement of domestic firms with foreign presence and overall absorptive capacity (Zhang et al. 2010; Girma 2005a). 


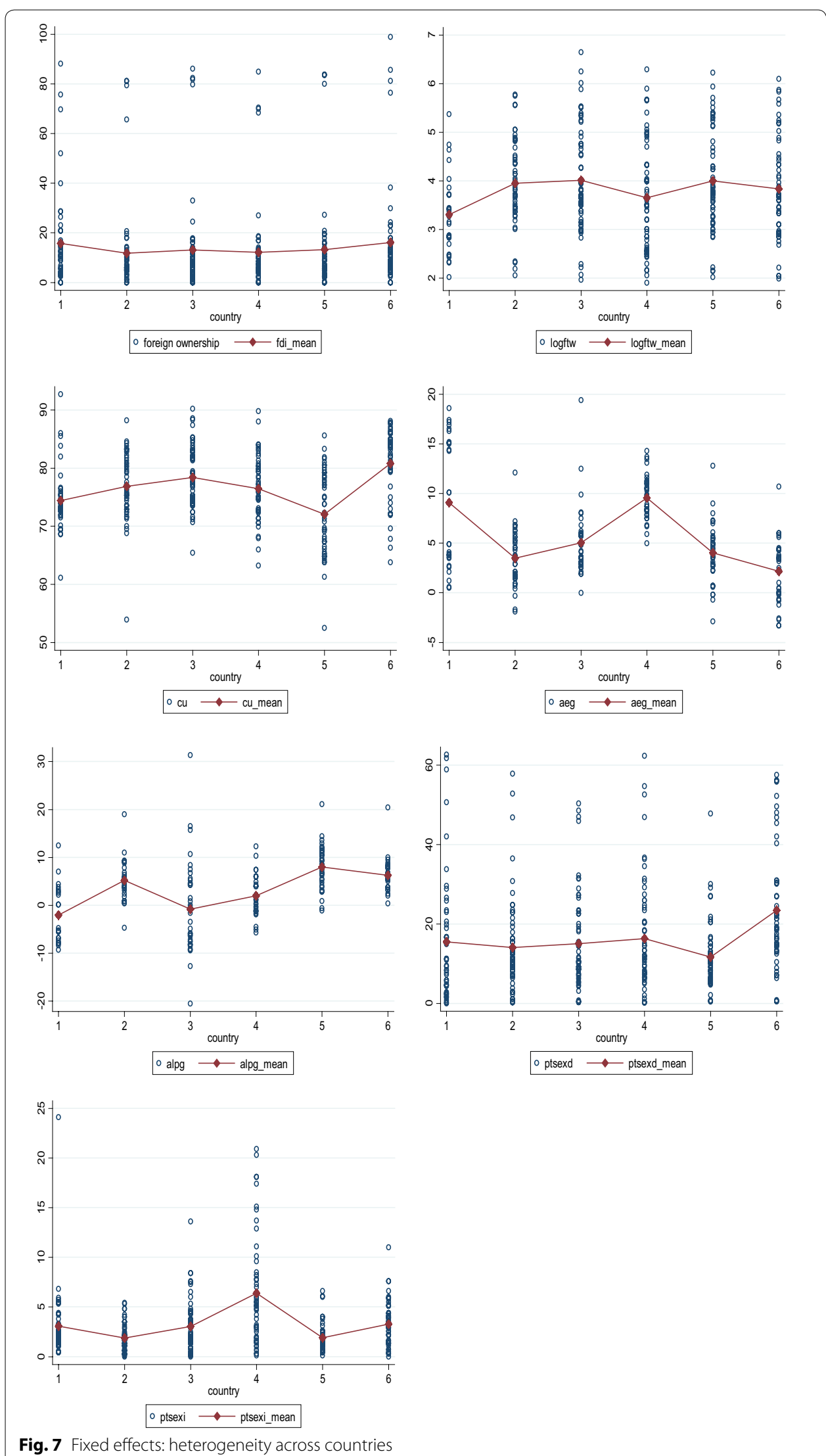



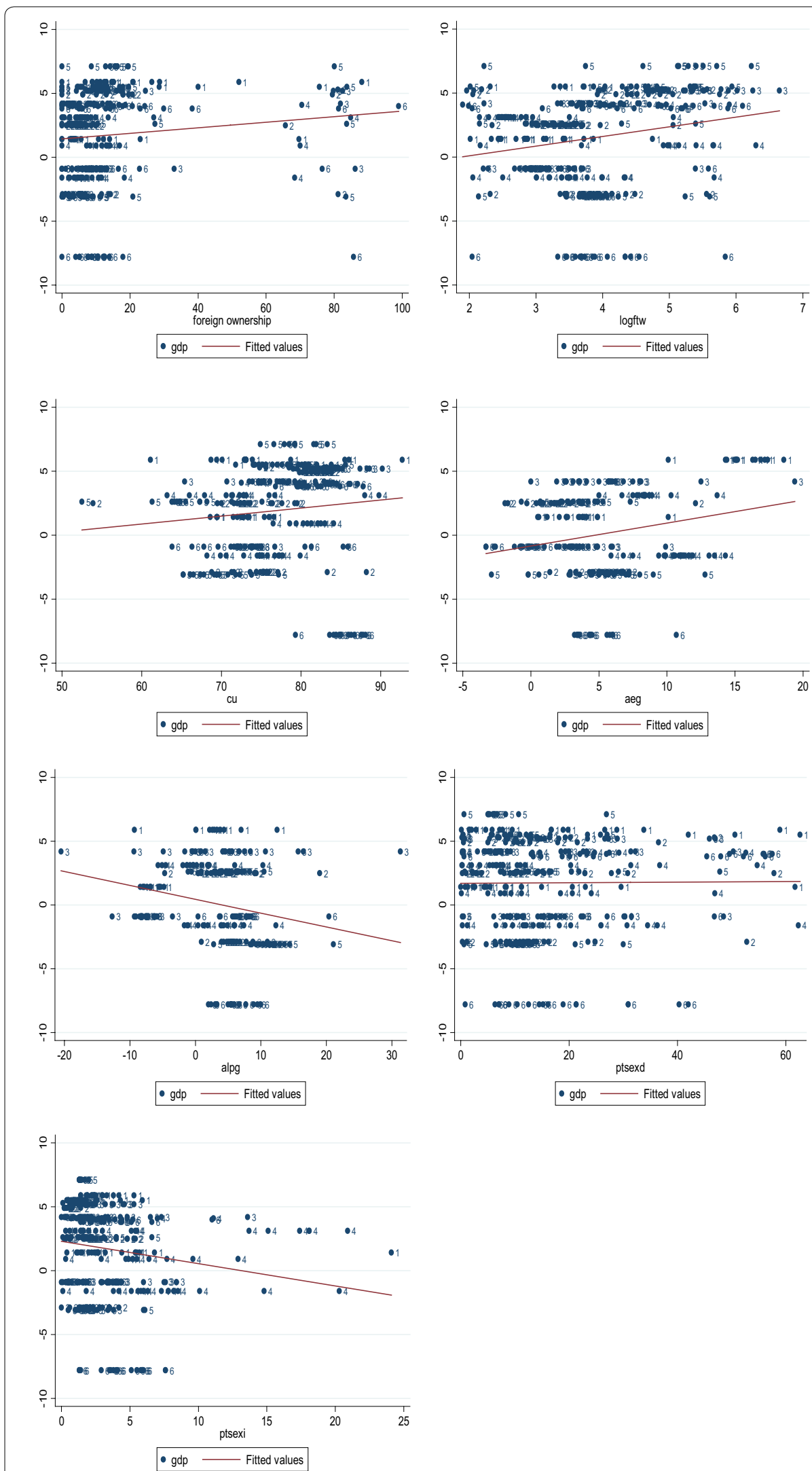

Fig. 8 Fitted values related to output 

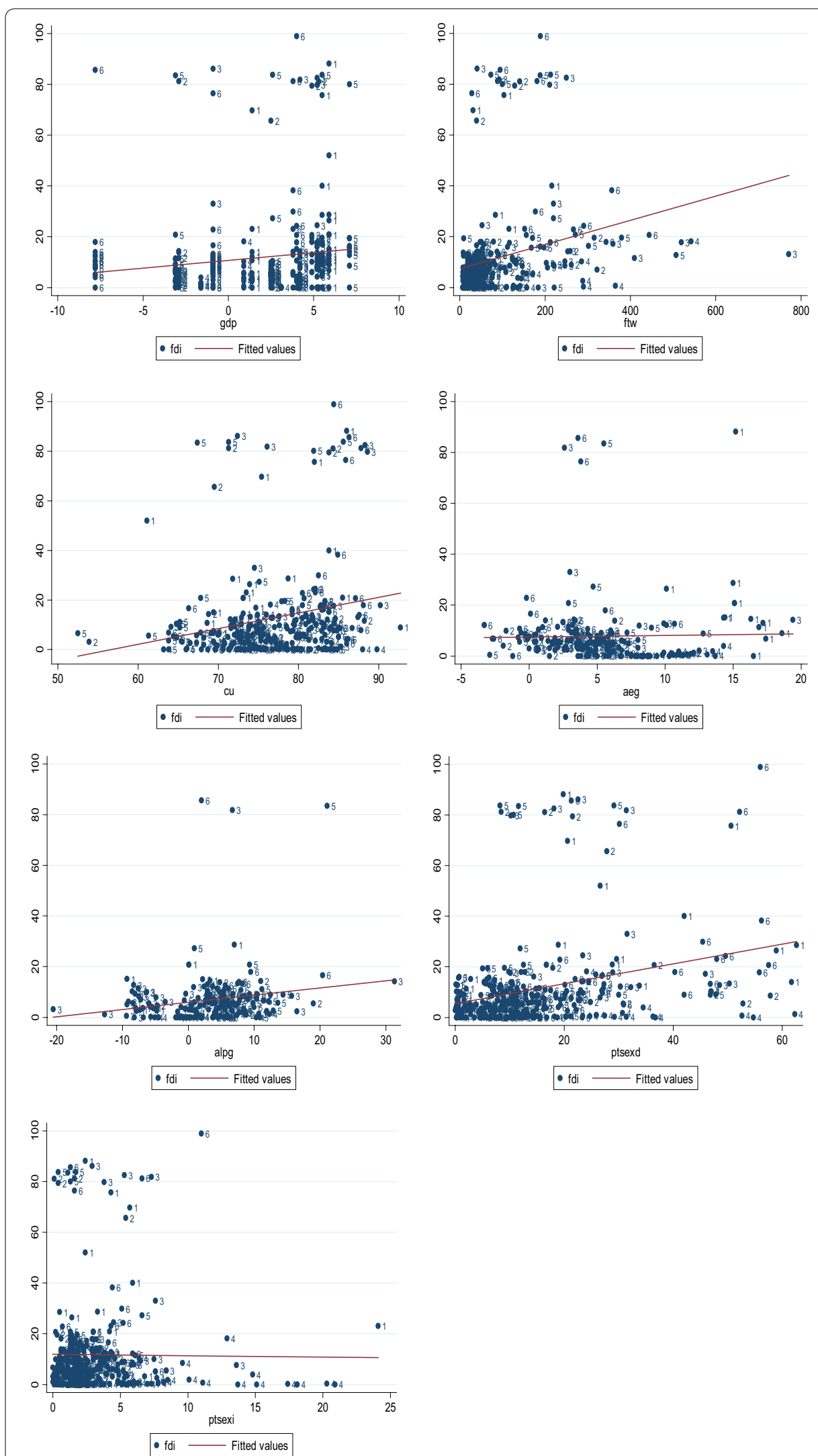

Fig. 9 Fitted values related to foreign ownership 
Through this model, we find that foreign direct investments leave their mark on the development of the economy through time. As a matter of fact, subsection. 10 and 12 in Table 6 show significant and positive outcomes provided that other variables are dropped, especially those that divert attention with their negative result (such as capacity utilization, average employment growth, average labor productivity growth and indirect exports). The constants in almost all models are high, significant and positive, describing steady and optimistic outlook. This shows certain exogenous output growth in early stage of entry of foreign ownership, which, according to fixed effects model, at present, depends on increase in general employment (mainly in labor-intensive sectors) and capital infused from abroad.

\section{Discussion}

The research utilizes variables in order to estimate the dependence of output to capital and labor. Further, we center on effects of foreign direct investments in Southeast European economies. The approach was twofold analysis: (1) a regression was used to see outcomes for every specific country separately and (2) fixed effects model to test the relationship of output to set of variables for the whole region of Southeast Europe. The results explained for each of the countries' economy and the whole region as a panel imply the way foreign ownership might influence business environment and economy's output.

According to the first path of examination of the basic hypothesis, it can be argued that foreign ownership has predisposed movements in domestic economies with constant increase in the capital base. Some countries show better results (Macedonia, Serbia and Croatia), others show more moderate ones (Albania and Bosnia and Herzegovina), and there are ones that are more driven by domestic movements rather than foreign (Slovenia). As established by present literature, it is evident that economies, and particularly transition economies, in the first wave of noteworthy influx of foreign ownership can increase overall output. On the other hand, productivity growth has shown to be latent in almost all analyzed countries, which might be a consequence to low level of technological advance and less endogenous development. The countries suffer of lag in labor force employment, and it is understandable as such developments come in later phases of FDI presence. Finally, strong evidence on the impact on exports has been noticed, especially direct exports.

The fixed effects model gave some worthy of note outcomes for the whole region. The relationship between foreign ownership and output is mixed, but descriptive data give confirmation of positive and upward trend. Capacity utilization had strong negative results generally attributed to unused or reduced firm production capacity which is mainly due to low level of domestic competitiveness and/or labor-intensive foreign direct investments with few high-tech firms. Further, the labor market (number of workers, employment and productivity growth) across the region has almost the same flaws; elevated rates of unemployment therefore reduced job quality and productivity. Even though on average productivity has been in upswing, it can be said that the labor market needs more restructuring which goes along with enterprise restructuring driven by foreign ownership and practices. Exports (especially direct exports) have been increasing steadily over time; nonetheless, more needs to be done in order to enhance exports 
especially by competitive domestic firms. Through this model, we find that foreign direct investments leave their mark on the development of the regional economy through time. Indeed, the constants in almost all models are high, significant and positive, describing steady and optimistic outlook.

There are positive ties of foreign direct investments to gross domestic product in all host economies. The indicated problem of productivity and especially of labor productivity is mostly related to previous levels and starting point at foreign ownerships' entry, which is in turn a measure of economy's sophistication. Nonetheless, gross domestic product and foreign direct investments are closely tied and the influence of foreign direct investments over gross domestic product is noteworthy.

Furthermore, it is apparent that foreign ownership advances throughout time because of imposed policies, as well as overall progress of the economy's gross domestic product owing to increased influx of foreign direct investments.

Received: 20 June 2015 Accepted: 12 March 2016

Published online: 31 March 2016

References

Acemoglu D, Griffith R, Aghion P, Zilibotti F (2010) Vertical integration and technology: theory and evidence. J Eur Econ Assoc 8(5):989-1033

Aitken BJ, Harrison AE (1999) Do domestic firms benefit from direct foreign investment? Evidence from Venezuela. Am Econ Rev 89(3):605-618

Aitken B, Hanson GH, Harrison AE (1997) Spillovers, foreign investment, and export behavior. J Int Econ 43(1-2):103-132

Aizenman J (2003) Volatility, employment and the patterns of FDI in emerging markets. J Dev Econ 72(2):585-601

Alfaro L, Chanda A, Kalemli-Ozcan S, Sayek S (2004) FDI and economic growth: the role of local financial markets. J Int Econ 64(1):89-112

Apostolov M (2011) Governance and Enterprise Restructuring: the Case of Macedonia. Trans Stud Rev 18(2):299-309

Apostolov M (2013a) Governance and enterprise restructuring in Southeast Europe. Int J Soc Econ 40(8):680-691

Apostolov M (2013b) Governance and enterprise restructuring in Southeast Europe: gross domestic product and foreign direct investments. Corp Gov Int J Bus Soc 13(4):431-438

Bailey D, Driffield N (2007) Industrial policy, FDI and employment: still 'missing a strategy'. J Ind Compet Trade 7(3-4):189-211

Balasubramanyam VN, Salisu M, Sapsford D (1996) Foreign direct investment and growth in EP and is countries. Econ J 106(434):92-105

Barrios S, Görg H, Strobl E (2011) Spillovers through backward linkages from multinationals: measurement matters! Eur Econ Rev 55(6):862-875

Barro RJ (1998) Notes on growth accounting. National Bureau of Economic Research Working Paper Series, No. 6654

Barro R, Sala-i-Martin X (1997) Technological diffusion, convergence, and growth. J Econ Growth 2(1):1-26

Beugelsdijk S, Smeets R, Zwinkels R (2008) The impact of horizontal and vertical FDI on host's country economic growth. Int Bus Rev 17(4):452-472

Blalock G, Gertler PJ (2008) Welfare gains from Foreign Direct Investment through technology transfer to local suppliers. J Int Econ 74(2):402-421

Blanchard O (1998) The economics of post-communist transition. Oxford University Press, Oxford

Blomström M, Kokko A (1998) Multinational corporations and spillovers. J Econ Surv 12(3):247-277

Blomström M, Sjöholm F (1999) Technology transfer and spillovers: does local participation with multinationals matter? Eur Econ Rev 43(4-6):915-923

Blomström Magnus, Kokko A, Zejan M (1994) Host country competition, labor skills, and technology transfer by multinationals. Weltwirtschaftliches Archiv 130(3):521-533

Borensztein E, De Gregorio J, Lee JW (1998) How does foreign direct investment affect economic growth? J Int Econ 45(1):115-135

Brainard SL (1997) An empirical assessment of the proximity-concentration trade-off between multinational sales and trade. Am Econ Rev 87(4):520-544

Cabrilo S, Uzelac Z, Cosic I (2009) Researching indicators of organizational intellectual capital in Serbia. Journal of Intellectual Capital 10(4):573-587

Castellani D, Zanfei A (2007) Multinational companies and productivity spillovers: is there a specification error? Applied Economics Letters 14(14):1047-1051

Caves RE (2007) Multinational enterprise and economic analysis. Cambridge University Press, Cambridge

Damijan JP, Rojec M, Majcen B, Knell M (2013) Impact of firm heterogeneity on direct and spillover effects of FDI: microevidence from ten transition countries. J Comp Econ 41(3):895-922 
Denison EF (1962) Why growth rates differ, postwar experience in nine western countries. Brookings Institution, Washington

Djankov S, Hoekman B (2000) Foreign investment and productivity growth in Czech enterprises. World Bank Econ Rev 14(1):49-64

Djankov S, Murrell P (2002) Enterprise restructuring in transition: a quantitative survey. J Econ Lit 40(3):739-792

Dosi G, Soete L (1983) Technology gaps and cost-based adjustment: some explorations on the determinants of international competitiveness. Metroeconomica 35(3):197-222

Filatotchev I, Strange R, Piesse J, Lien Y-C (2007) FDI by firms from newly industrialised economies in emerging markets: corporate governance, entry mode and location. J Int Bus Stud 38(4):556-572

Frankel JA, Rose AK (1996) Currency crashes in emerging markets: an empirical treatment. J Int Econ 41(3-4):351-366

Freedman DA (2005) Statistical models: theory and practice. Cambridge University Press, Cambridge

Freedman D, Pisani R, Purves R (2007) Statistics. W.W. Norton \& Company, New York

Fu X (2008) Foreign direct investment, absorptive capacity and regional innovation capabilities: evidence from China. Oxf Dev Stud 36(1):89-110

Girma S (2005a) Absorptive capacity and productivity spillovers from FDl: a threshold regression analysis*. Oxford Bull Econ Stat 67(3):281-306

Girma S (2005b) Technology transfer from acquisition FDI and the absorptive capacity of domestic firms: an empirical investigation. Open Economies Review 16(2):175-187

Girma S, Greenaway D, Wakelin K (2001) Who benefits from foreign direct investment in the UK? Scott J Polit Econ 48(2):119-133

Girma, S., Görg, H. \& Pisu, M. 2008. Exporting, linkages and productivity spillovers from foreign direct investment/Exportation, effets d'entraînement, et effets externes de productivité en provenance de l'investissement direct de l'étranger. Can J Econ/Rev Can Écon 41 (1):320-40

Glass AJ, Saggi K (1998) International technology transfer and the technology gap. J Dev Econ 55(2):369-398

Glass AJ, Saggi K (2002) Multinational firms and technology transfer. Scand J Econ 104(4):495-513

Görg H, Strobl E (2003a) 'Footloose' multinationals? Manch Sch 71(1):1-19

Görg H, Strobl E (2003b) Multinational companies, technology spillovers and plant survival. Scand J Econ 105(4):581-595

Haddad M, Harrison A (1993) Are there positive spillovers from direct foreign investment?: evidence from panel data for Morocco. J Dev Econ 42(1):51-74

Hanousek J, Kočenda E, Maurel M (2011) Direct and indirect effects of FDI in emerging European markets: a survey and meta-analysis. Econ Syst 35(3):301-322

Haskel JE, Pereira SC, Slaughter MJ (2007) Does inward foreign direct investment boost the productivity of domestic firms? Rev Econ Stat 89(3):482-496

Hubert F, Pain N (2001) Inward investment and technical progress in the United Kingdom manufacturing sector. Scott J Polit Econ 48(2):134-147

Jaklič A, Damijan JP, Rojec M, Kunčič A (2014) Relevance of innovation cooperation for firms' innovation activity: the case of Slovenia. Econ Res Ekon Istraž 27(1):645-661

Javorcik BS (2004) Does foreign direct investment increase the productivity of domestic firms? In search of spillovers through backward linkages. Am Econ Rev 94(3):605-627

Javorcik BS (2014) Does FDI bring good jobs to host countries? The World Bank Research Observer

Javorcik BS, Spatareanu M (2011) Does it matter where you come from? Vertical spillovers from foreign direct investment and the origin of investors. J Dev Econ 96(1):126-138

Jorgenson D, Griliches Z (1967) The explanation of productivity change. Rev Econ Stud 34(99):249-280

Kathuria V (2000) Productivity spillovers from technology transfer to Indian manufacturing firms. J Int Dev 12(3):343-369

Keller W, Yeaple SR (2009) Multinational enterprises, international trade, and productivity growth: firm-level evidence from the United States. Rev Econ Stat 91(4):821-831

Kendrick JW (1961) Productivity trends in the United States. Princeton University Press, Princeton

Kokko A (1994) Technology, market characteristics, and spillovers. J Dev Econ 43(2):279-293

Komnenic B, Pokrajčić D (2012) Intellectual capital and corporate performance of MNCs in Serbia. J Intell Cap 13(1):106-119

Konings J (2001) The effects of foreign direct investment on domestic firms. Econ Transit 9(3):619-633

La Porta R, Shleifer A (2014) Informality and Development. J Econ Perspect 28(3):109-126

Lane TD, Lipschitz L, Mourmouras A (2002) Capital flows to transition economies: master or servant. International Monetary Fund, Washington

Liebscher K (2005) European economic integration and south-east Europe: challenges and prospects. Edward Elgar Publishing Incorporated, Cheltenham

Lim EG (2001) Determinants of, and the relation between, foreign direct investment and growth: a summary of the recent Literature. International Monetary Fund, Washington

Liu X, Siler P, Wang C, Wei Y (2000) Productivity spillovers from foreign direct investment: evidence from UK industry level panel data. J Int Bus Stud 31(3):407-425

Markusen JR (1995) The boundaries of multinational enterprises and the theory of international trade. J Econ Perspect 9(2):169-189

Merlevede B, Schoors K, Spatareanu M (2014) FDI spillovers and time since foreign entry. World Dev 56:108-126

Monastiriotis V, Alegria R (2011) Origin of FDI and intra-industry domestic spillovers: the case of Greek and European FDI in Bulgaria. Rev Dev Econ 15(2):326-339

Nastav B, Bojnec Š (2007) The shadow economy in Bosnia and Herzegovina, Croatia, and Slovenia: the labor approach. Eastern European Economics 45(1):29-58

Popov D (2004) Privatization and foreign investments: the case of Serbia and Montenegro. Trans Stud Rev 11(3):196-209

Popov D (2010) The importance of foreign capital for the economic stability of Serbia. Trans Stud Rev 17(4):777-789

Romer PM (1990) Endogenous technological change. J Polit Econ 98(5):S71-S102 
Sánchez-Sellero P, Rosell-Martínez J, García-Vázquez JM (2014) Absorptive capacity from foreign direct investment in Spanish manufacturing firms. Int Bus Rev 23(2):429-439

Smarzynska Javorcik B (2004) The composition of foreign direct investment and protection of intellectual property rights: evidence from transition economies. Eur Econ Rev 48(1):39-62

Solow RM (1957) Technical change and the aggregate production function. Rev Econ Stat 39(3):312-320

Tan D, Meyer KE (2010) Business groups' outward FDI: a managerial resources perspective. J Int Manag 16(2):154-164

Trifunović D, Ristić B, Ivković M, Tanasković S, Italiano L, Tattoni S (2009) FDl's impact on transitional countries, Serbia as a rational choice: the FIAT-ZASTAVA case. Trans Stud Rev 16(2):269-286

Vera-Cruz AO, Dutrénit G (2005) Spillovers from MNCs through worker mobility and technological and managerial capabilities of SMEs in Mexico. Innovation 7(2-3):274-297

Wheeler D, Mody A (1992) International investment location decisions: the case of U.S. firms. J Int Econ 33(1-2):57-76

Wooldridge JM (2002) Econometric analysis of cross section and panel data. MIT Press, Cambridge

Wooldridge J (2015) Introductory econometrics: a modern approach. Cengage Learning, Boston

World Bank T (2015) Enterprise Surveys. The World Bank. http://www.enterprisesurveys.org

Xu X, Sheng Y (2012) Productivity spillovers from foreign direct investment: firm-level evidence from China. World Dev 40(1):62-74

Zhang Y, Li H, Li Y, Zhou L-A (2010) FDI spillovers in an emerging market: the role of foreign firms' country origin diversity and domestic firms' absorptive capacity. Strateg Manag J 31(9):969-989

Zhao $L(1998)$ The impact of foreign direct investment on wages and employment. Oxf Econ Pap 50(2):284-301

\section{Submit your manuscript to a SpringerOpen ${ }^{\circ}$ journal and benefit from:}

- Convenient online submission

- Rigorous peer review

- Immediate publication on acceptance

- Open access: articles freely available online

- High visibility within the field

- Retaining the copyright to your article

Submit your next manuscript at $\mathbf{s p r i n g e r o p e n . c o m ~}$ 